\title{
Kepadatan dan Pola Penyebaran Ficus spp. Di Stasiun Penelitian Cabang Panti Taman Nasional Gunung Palung Kalimantan Barat
}

\author{
Sumihadi $^{1}$, Rafdinal ${ }^{1}$, Riza Linda ${ }^{1}$ \\ Program Studi Biologi, Fakultas MIPA, Universitas Tanjungpura, \\ Jl. Prof. Dr. H. Hadari Nawawi, Pontianak, \\ Email: sumihadishine@gmail.com
}

\begin{abstract}
Ficus is key species that commonly lives in tropical region because of its ability to bear fruit year around, thus so many kind of Ficus that become source of food and habitat to animals. The aim of the research to determine the density and distribution pattern of Ficus spp. at Research Station of Gunung Palung National Park in May until June 2018. The observation of Ficus spp. is done by random sampling method on 5 different locations, there are lowland granite, warmth, sands stone, freshwater swamp and alluvial land. The result showed that there are 4 species of Ficus with density ranges 16-60 individuals/ha and the distributions patterns are uniform and grouped.
\end{abstract}

Keywords: Ficus, density, distribution pattern, Gunung Palung

\section{PENDAHULUAN}

Taman Nasional Gunung Palung (TNGP) merupakan salah satu Taman Nasional yang terdapat di Kalimantan Barat. Ekosistem yang ada di kawasan TNGP memiliki keanekaragaman hayati yang tinggi, meliputi keanekaragaman flora maupun fauna yang tersebar di delapan ekosistem yang berbeda yaitu hutan rawa gambut, hutan rawa air tawar, hutan tanah aluvial, hutan kerangas, hutan batu berpasir dataran rendah, hutan granit dataran rendah, hutan granit dataran tinggi dan hutan pegunungan. Selain itu, TNGP juga menjadi habitat penting bagi beragam jenis tumbuhan, salah satunya ialah tumbuhan Ficus spp.

Ficus spp. berasal dari famili Moraceae yang merupakan spesies kunci yang umum dijumpai pada kawasan tropis karena mampu berbuah sepanjang tahun, sehingga banyak jenis Ficus spp. yang menjadi sumber pakan dan sumber habitat berbagai jenis satwa. Keragaman bentuk hidup Ficus spp. menjadi hal menarik dan mudah dijumpai di berbagai tipe ekosistem (Hao et al, 2016).

Ficus memiliki Fungsi ekologi antara lain ialah menjaga tata air serta menguatkan lereng secara alami karena struktur perakarannya yang mampu mengikat tanah dengan baik, kemudian melalui tajuk yang rimbun Ficus spp. memiliki kemampuan yang tinggi untuk menyerap $\mathrm{CO}_{2}$ dan gas polutan lainnya di udara (Ulum, 2009).

Beberapa penelitian terdahulu yang telah dilakukan di kawasan Taman Nasional Gunung Palung (TNGP) antara lain telah dilakukan oleh Rusda (2013) tentang perilaku bersarang orangutan Kalimantan di tipe habitat yang berbeda dan penelitian Sidiq et al. (2015) tentang karakteristik dan kerapatan sarang orangutan serta penelitian yang dilakukan oleh Muhlis (2017), tentang inventarisasi pohon pakan orangutan. Penelitian tentang Ficus spp. terkait kepadatan dan pola penyebaran belum pernah dilakukan di Stasiun Penelitian Cabang Panti, TNGP.

Tujuan penelitian ini yaitu untuk mengetahui kepadatan dan pola penyebaran Ficus spp. di Stasiun Penelitian Cabang Panti, Taman Nasional Gunung Palung

\section{METODE PENELITIAN}

\section{Waktu dan Tempat Penelitian}

Penelitian ini dilaksanakan mulai dari bulan Mei hingga bulan Juni 2018 di Stasiun Penelitian Cabang Panti, Taman Nasional Gunung Palung yang terletak di Kabupaten Ketapang dan Kabupaten Kayong Utara, Kalimantan Barat. 


\section{Deskripsi Lokasi Penelitian}

Stasiun Penelitian Cabang Panti (SPCP), Taman Nasional Gunung Palung memiliki luas area penelitian $2.100 \mathrm{H}$ dari keseluruhan luas area $90.000 \quad H \quad$ Taman Nasional Gunung Palung.Terdapat delapan tipe habitat yaitu hutan rawa gambut, hutan rawa air tawar, hutan dataran aluvial, hutan kerangas, hutan batu berpasir, hutan granit dataran rendah, hutan granit dataran tinggi dan hutan pegunungan. Letak tipe habitat di Stasiun Penelitian Cabang Panti disajikan pada Gambar 1.

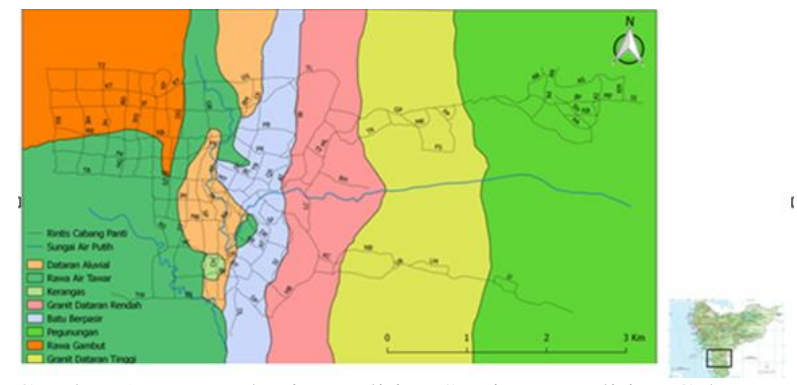

Gambar 1. Peta Lokasi Penelitian Stasiun Penelitian Cabang Panti, Taman Nasional Gunung Palung

Stasiun Penelitian Cabang Panti terletak di kawasan Taman Nasional Gunung Palung (TNGP), secara geografis Taman Nasional ini terletak pada koordinat $01^{\circ} 00^{\prime}-01^{\circ} 20^{\prime}$ LS dan $109^{\circ} 00^{\prime}-110^{\circ} 25^{\prime}$ BT. Kawasan Taman Nasional Gunung Palung yang berada di daerah hilir termasuk ke dalam tiga Daerah Aliran Sungai (DAS), yaitu sebelah utara dan timur termasuk ke dalam DAS Simpang, sebelah timur DAS Pawan dan sebelah selatan termasuk DAS. Sebagian besar habitat Taman Nasional Gunung Palung didominasi oleh jenis-jenis tumbuhan dari Famili Dipterocarpaceae seperti meranti (Shorea spp.), kruing (Dipterocarpus spp.) dan kapur (Dryobalanops spp.). selain itu ditemukan juga durian (Durio carinatus), rambutan hutan (Nephelium sp.), pluntan (Arthocarpus sp.), dan ara (Ficus spp.) (Badan Planologi Kehutanan, 2002).

\section{Alat dan Objek Penelitian}

Alat-alat yang digunakan pada penelitian ini adalah GPS (Global Positioning System), kamera digital, kompas, meteran gulung, parang, patok, peta lokasi penelitian, pita tagging, spidol permanen dan tali rafia. Bahan yang digunakan adalah tumbuhan Ficus spp. yang terdapat di dalam petak contoh.
}

\section{Prosedur Penelitian}

Penentuan Lokasi Penelitian

Penentuan lokasi pada penelitian ini ada lima tipe habitat yaitu habitat rawa air tawar, habitat dataran aluvial, habitat batu berpasir, habitat granit dataran rendah dan habitat kerangas. Habitat granit dataran tinggi dan habitat pegunungan tidak termasuk dalam lokasi sampling karena sulit untuk diakses. Habitat rawa gambut juga tidak termasuk dalam lokasi sampling karena saat musim hujan habitat tersebut tergenang air sehingga sulit dalam pembuatan plot pengamatan.

\section{Metode Pengambilan Sampel}

Posisi plot di lapangan ditentukan dengan menggunakan metode Random Sampling. Masingmasing habitat dibuat plot pengamatan sebanyak 3 plot dengan ukuran plot pengamatan $20 \mathrm{~m}$ x $50 \mathrm{~m}$, Pengamatan dilakukan pada tumbuhan Ficus spp. yang terdapat di dalam petak contoh.

\section{Analisis Data}

a. Kepadatan

Analisis kepadatan didasarkan formula Brower \& Zar ( 1977) dengan formula berikut:

$$
\mathrm{Di}=\frac{n i}{A}
$$

Keterangan:

Di = kepadatan Ficus spp.

$\mathrm{ni}=$ jumlah individu

$\mathrm{A}=$ luas plot

\section{b. Pola Penyebaran}

Analisis pola penyebaran didasarkan formula Krebs (1989) dengan formula berikut:

$I d=n\left[\frac{\sum x^{2}-\sum x}{\left(\sum x\right)^{2}-\sum x}\right]$

Keterangan:

Id : Indeks dispersi Morisita

n : jumlah petak

$\Sigma \mathrm{x} \quad$ : total dari jumlah individu suatu oganisme dalam kuadrat

$\Sigma \times 2$ : total dari kuadrat jumlah individu dalam kuadrat

Jika:

Id $=1$ pola penyebaran adalah acak

Id $<1$ pola penyebaran adalah seragam

Id $>1$ pola penyebaran adalah mengelompok 


\section{HASIL DAN PEMBAHASAN}

\section{Hasil \\ Jenis-jenis Ficus pada lokasi pengamatan di Stasiun Penelitian Cabang Panti, Taman Nasional Gunung Palung}

Berdasarkan hasil penelitian di Stasiun Penelitian Cabang Panti, Taman Nasional Gunung Palung didapatkan 4 jenis Ficus yang terdiri atas Ficus punctata L., F. benjamina L., Ficus sp. 1 dan Ficus sp. 2. Jumlah total individu Ficus yang didapatkan yaitu 38 individu. Spesies yang paling banyak didapat ialah Ficus punctata L. Jumlah dan jenis Ficus yang didapatkan tersaji pada Tabel 1 .

Tabel 1. Jumlah dan jenis Ficus yang didapatkan pada setiap lokasi pengamatan

\begin{tabular}{|c|c|c|c|c|c|c|c|}
\hline \multirow{2}{*}{ No } & \multirow{2}{*}{ Nama Jenis } & \multicolumn{5}{|c|}{ Lokasi Pengamatan } & \multirow{2}{*}{$\sum$ Ind } \\
\hline & & GDR & KER & $\mathrm{BP}$ & RAT & DA & \\
\hline 1 & Ficus punctata $L$. & 8 & 4 & 3 & 1 & 2 & 18 \\
\hline 2 & F. benjamina $L$. & 1 & 3 & 1 & 2 & 1 & 8 \\
\hline 3 & F. sp. 1 & 1 & 3 & 1 & 0 & 0 & 5 \\
\hline 4 & F. sp. 2 & 2 & 0 & 2 & 2 & 1 & 7 \\
\hline Total & & 12 & 10 & 7 & 5 & 4 & 38 \\
\hline
\end{tabular}

Air Tawar, DA: Dataran Aluvial, $\sum$ Ind: Jumlah individu

Berdasarkan hasil penelitian diperoleh jenis Ficus diantarannya Ficus punctata L., F. benjamina L., Ficus sp. 1 dan Ficus sp. 2, keempat spesies ini memiliki perbedaan karakter morfologi baik dari batang, daun dan buah. Karakter morfologi jenisjenis Ficus disajikan dalam Gambar 2.

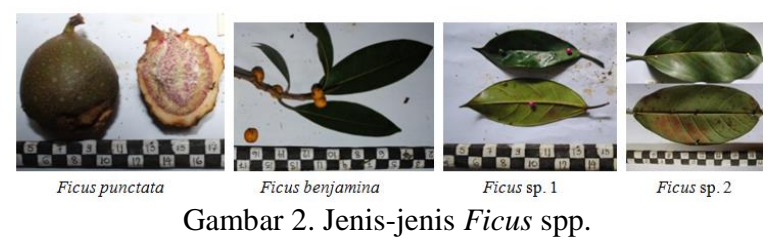

Berdasarkan pengamatan ciri-ciri morfologi terhadap Ficus punctata L. memiliki habitus berupa liana yang menempel pada pohon inang, bentuk batang pipih sampai bulat dan memiliki akar yang merambat ke pohon inang. Kulit pohon berbau khas dan memiliki getah berwarna putih pekat. Helaian daun berbentuk bulat telur sampai lonjong dan pertulangan daun yang menonjol. Buah $F$. punctata $L$. Berbentuk bulat telur dan memiliki tangkai buah. Buah muncul pada hujung tangkai yang tidak terdapat daun. Buah berdaging dan kulit buah yang mentah berwarna hijau berbintik putih kekuningan sedangkan kulit buah yang matang berwarna cokelat. Biji berbentuk bulat berukuran kecil, berwarna merah muda keunguan sampai cokelat kehitaman.
Berdasarkan pengamatan ciri-ciri morfologi terhadap Ficus benjamina L. Memiliki habitus berupa pohon yang besar, tinggi dan rindang. Batang berbentuk tegak dan bulat, kulit batang berwarna cokelat kehitaman dan memiliki permukaan batang yang kasar, di bagian batang terdapat akar udara yang tumbuh menjuntai ke bawah. sedangkan untuk akar pokoknya sendiri, adalah akar tunggang yang kuat dan kokoh. Pohon ini mempunyai percabangan batang simpodial. Daun $F$. benjamina $L$. memiliki bentuk lonjong dengan tepi merata dan memiliki ujung daun meruncing. Buah $F$. benjamina $L$. Berbentuk bulat sampai lonjong. Buah muncul pada ketiak daun. Buah tergolong buah buni dan kulit buah yang muda berwarna kuning pucat sedangkan kulit buah yang matang berwarna kuning tua hingga cokelat kehitaman. Biji berbentuk bulat berwarna putih dan mempunyai tekstur yang keras.

Berdasarkan pengamatan ciri-ciri morfologi terhadap Ficus sp. 1 memiliki habitus berupa hemiepifit yang bentuk pertumbuhannya adalah pohon ara pencekik. Batang berbentuk pipih sampai bulat yang mencekik pohon inang. Daun Ficus sp. 1 memiliki bentuk persegi panjang hingga lonjong, dengan ujung daun runcing, bagian tepi daun rata, permukaan daun licin dan mengkilap, daging daun sedikit kaku. Permukaan daun bagian atas berwarna hijau tua terang dan permukaan daun bagian bawah berwarna hijau muda terang. Pertulangan daun menyirip, tangkai daun panjangnya $1-2 \mathrm{~cm}$ dan terdapat bulu-bulu halus berwarna putih kekuningan dan berwarna cokelat apabila sudah mengering.

Berdasarkan pengamatan ciri-ciri morfologi terhadap Ficus sp. 2 memiliki habitus berupa hemiepifit. Batang lebih kecil dibandingkan pohon inang, tidak bisa tumbuh keatas tanpa pohong inang. Batang berbentuk bulat yang tumbuh berdampingan dengan pohon inang, permukaan batang halus, memiliki cabang yang banyak dan ranting yang gundul apabila daun telah gugur. Tinggi pohon mencapai 20 hingga 50 meter, kulit apabila dilukai mengeluarkan getah berwarna putih. Daun Ficus sp. 2 memiliki bentuk bulat telur dengan ujung daun membulat, bagian tepi daun rata, permukaan daun licin, daging daun seperti kertas. Permukaan daun bagian atas berwarna hijau tua dan permukaan daun bagian bawah berwarna hijau muda. Duduk daun berselang-seling, Pertulangan daun menyirip dengan pangkal daun sedikit melengkung. Permukaan bawah daun bias dilihat dengan jelas vena daun menonjol. 
Kepadatan Ficus spp. di Stasiun Penelitian Cabang Panti, Taman Nasional Gunung Palung

Berdasarkan penelitian yang telah dilakukan terhadap kepadatan Ficus spp. di lima habitat yang berada di Stasiun Penelitian Cabang Panti, Taman Nasional Gunung Palung didapatkan hasil yang tersaji pada Tabel 2 .

Tabel 2. Kepadatan Ficus spp. di Stasiun Penelitian Cabang Panti, TamanNasional Gunung Palung

\begin{tabular}{|c|c|c|}
\hline $\begin{array}{l}\text { Lokasi } \\
\text { Pengamatan }\end{array}$ & $\begin{array}{l}\text { Nama } \\
\text { Spesies }\end{array}$ & $\begin{array}{l}\text { Kepadatan } \\
\text { (ind/ha) }\end{array}$ \\
\hline \multirow{4}{*}{ Granit Dataran Rendah } & Ficus punctata & 26 \\
\hline & Ficus benjamina & 3 \\
\hline & Ficus sp. 1 & 3 \\
\hline & Ficus sp. 2 & 6 \\
\hline \multirow[t]{4}{*}{ Kerangas } & Ficus punctata & 13 \\
\hline & Ficus benjamina & 10 \\
\hline & Ficus sp. 1 & 10 \\
\hline & Ficus sp. 2 & 0 \\
\hline \multirow[t]{4}{*}{ Batu Berpasir } & Ficus punctata & 10 \\
\hline & Ficus benjamina & 3 \\
\hline & Ficus sp. 1 & 3 \\
\hline & Ficus sp. 2 & 6 \\
\hline \multirow[t]{4}{*}{ Rawa Air Tawar } & Ficus punctata & 3 \\
\hline & Ficus benjamina & 6 \\
\hline & Ficus sp. 1 & 0 \\
\hline & Ficus sp. 2 & 6 \\
\hline \multirow[t]{4}{*}{ Dataran Aluvial } & Ficus punctata & 6 \\
\hline & Ficus benjamina & 3 \\
\hline & Ficus sp. 1 & 0 \\
\hline & Ficus sp. 2 & 3 \\
\hline
\end{tabular}

Berdasarkan tabel diatas jumlah individu tertinggi ialah Ficus punctata L. sebanyak 18 individu sedangkan jumlah terendah ialah Ficus sp. 1 sebanyak 5 individu. Kepadatan tertinggi Ficus punctata pada habitat granit dataran rendah yaitu sebanyak 26 individu/ha sedangkan kepadatan terendah Ficus sp. 1 karena tidak didapatkan pada habitat rawa air tawar dan habitat dataran aluvial.

Pola penyebaran Ficus spp. di Stasiun Penelitian Cabang Panti, Taman Nasional Gunung Palung

Berdasarkan analisis pola penyebaran Ficus spp. di lima habitat yang berada di Stasiun Penelitian Cabang Panti, Taman Nasional Gunung Palung memiliki pola penyebaran mengelompok dan seragam Tabel 3.

Tabel 3. Pola Penyebaran Ficus spp. di Stasiun Penelitian Cabang panti, Taman Nasional Gunung Palung

\begin{tabular}{llll}
\hline Lokasi & Nama & Indeks & Pola \\
Pengamatan & Spesies & Morisita & Penyebaran \\
\hline Granit Dataran Rendah & Ficus punctata & 1,392 & Mengelompok \\
& Ficus benjamina & 0 & Seragam \\
& Ficus sp. 1 & 0 & Seragam \\
Kerangas & Ficus sp. 2 & 0 & Seragam \\
& Ficus punctata & 0,499 & Seragam \\
& Ficus benjamina & 0 & Seragam \\
& Ficus sp. 1 & 0 & Seragam \\
& Ficus sp. 2 & 0 & Seragam
\end{tabular}

\begin{tabular}{llll} 
Batu Berpasir & Ficus punctata & 0 & Seragam \\
& Ficus benjamina & 0 & Seragam \\
& Ficus sp. 1 & 0 & Seragam \\
& Ficus sp. 2 & 0 & Seragam \\
Rawa Air Tawar & Ficus punctata & 0 & Seragam \\
& Ficus benjamina & 0 & Seragam \\
& Ficus sp. 1 & 0 & Seragam \\
& Ficus sp. 2 & 0 & Seragam \\
Dataran Aluvial & Ficus punctata & 0 & Seragam \\
& Ficus benjamina & 0 & Seragam \\
& Ficus sp. 1 & 0 & Seragam \\
& Ficus sp. 2 & 0 & Seragam \\
\hline
\end{tabular}

Pola penyebaran Ficus spp. dari lima habitat yang ada di Stasiun Penelitian Cabang Panti, Taman Nasional Gunung Palung memiliki pola penyebaran mengelompok dan seragam, serta tidak terdapat pola penyebaran acak. Ficus yang memiliki pola penyebaran mengelompok hanya Ficus punctata pada habitat granit dataran rendah sedangkan yang lainnya memiliki pola penyebaran seragam.

\section{Faktor lingkungan pada lokasi pengamatan}

Hasil pengukuran rerata faktor lingkungan $\mathrm{pH}$ tanah, kelembaban tanah, suhu udara dan kelembaban udara pada masing-masing lokasi pengamatan dapat dilihat pada Tabel 4 .

Tabel. 4 Faktor lingkungan pada lokasi pengamatan

\begin{tabular}{lllll}
\hline Habitat & $\begin{array}{l}\mathrm{pH} \\
\operatorname{tanah}\end{array}$ & $\begin{array}{l}\text { Kelembaban } \\
\text { tanah }(\%)\end{array}$ & $\begin{array}{l}\text { Suhu } \\
\text { Udara } \\
\left({ }^{0} \mathrm{C}\right)\end{array}$ & $\begin{array}{l}\text { Kelembaban } \\
\text { Udara }(\%)\end{array}$ \\
\hline GDR & 6,6 & 40 & 27 & 96 \\
KER & 5 & 90 & 27,6 & 99 \\
BP & $5,8-6,6$ & $40-50$ & 27 & 96 \\
RAT & 5,6 & 85 & 27,7 & 98 \\
DA & $5,8-6,6$ & $40-55$ & 27,6 & 90 \\
\hline \multicolumn{5}{r}{ Keterangan: GDR: Granit Dataran Rendah, KER: Kerangas, BP: Batu Berpasir, RAT: Rawa } \\
\multicolumn{5}{c}{ Air Tawar, DA: Dataran Aluvial, }
\end{tabular}

\section{Pembahasan}

Jenis tumbuhan Ficus yang didapatkan di Stasiun Penelitian Cabang Panti, Taman Nasional Gunung Palung pada penelitian ini sebanyak 4 jenis yaitu Ficus punctata L., F. benjamina L. Ficus sp. 1 dan Ficus sp. 2. Berdasarkan hasil penelitian ini, Ficus yang ditemukan pada habitat kerangas, rawa air tawar dan dataran aluvial sebanyak 3 jenis sedangkan pada habitat granit datran rendah dan habitat batu berpasir ditemukan 4 jenis Ficus. Jumlah total individu Ficus yang didapatkan yaitu 38 individu. Spesies yang paling banyak didapat ialah Ficus punctata $L$.

Menurut Berg \& Corner (2010) F. punctata L. Merupakan tumbuhan pemanjat yang memiliki ciri-ciri akar berkayu, akar bebas dari batang dan cabang untuk menempel pada batang pohon inang dan terkadang merambat di tanah. Batang $F$. punctata $L$. apabila dilukai akan mengeluarkan 
getah berwarna putih susu, duduk daun pada batang berselang-seling, helaian daun kasar dan lonjong hingga berbentuk bulat panjang untuk membentuk sabit lebar, lebar daun $0,5 \mathrm{~cm}-7,5 \mathrm{~cm}$, berwarna hijau tua mengkilap di permukaan atas, hijau muda di permukaan bawah, dengan venasi terjaring menonjol. Tepi daun dan bagian bawah berbulu jarang, tangkai daun berbulu, bunga dioecious, dengan berbagai tanaman menghasilkan bunga jantan atau betina, buah berbentuk bulat telur, berdaging dan diproduksi di sepanjang cabang yang tidak berdaun. Buah berwarna dari hijau menjadi oranye berbintikbintik, berubah ungu kehitaman hingga coklat dan memiliki aroma buah ketika terlalu matang.

Musim buah yang terjadi menghasilkan buah dalam jumlah besar sehingga buah yang jatuh akan menumpuk di tanah tepat di bawah pohon inang. Penyerbukan dilakukan oleh tawon ara kemudian buah yang matang dimakan oleh hewan pemakan buah seperti kelelawar, rangkong, orangutan dan monyet. Ficus punctata hidup pada pohon inangnya, habitat yang cocok untuk pertumbuhannya meliputi dataran rendah, dataran tinggi hingga di sepanjang tepi jalan dan aliran sungai (Berg \& Corner, 2010).

Menurut Gilman \& Watson (2011). F. benjamina L. berhabitus pohon dengan tinggi 13-18 m, diameter tajuk 18-30 m, model tajuk menggantung dan tipe pertumbuhan cepat. Batang berkayu, berbentuk silinder namun tidak beraturan, permukaan batang kasar dan berlentisel, arah tumbuh batang dan cabang condong ke atas. Kulit pohon bagian luar beralur dan kulit pohon bagian dalam bergetah putih yang aromatik. Daun tunggal, tepi rata sampai berombak, bentuk daun ovate sampai elliptic, pertulangan menyirip, panjang daun $5-10 \mathrm{~cm}$ dan berwarna hijau. Tangkai daun silinder, panjang kurang dari $2,5 \mathrm{~cm}$, permukaan daun licin dan kuncup terbungkus stipula bumbung kecil hijau di axillar

Menurut Hemmer et al. (2004). F. benjamina $L$. memiliki ciri khas berupa akar gantung yang menjulur dari atas ke bawah dalam jumlah banyak, sehingga tampak seperti garis-garis vertikal yang menopang pohon tersebut.

Menurut Boer \& Sosef (1998) Akar gantung ini bervariasi diameternya menjuntai menutupi batang utama. Akar gantung yang semula berdiameter kecil tumbuh berkembang menjadi besar menutupi batang utama. Akar yang berada paling dekat dengan batang utama berdiameter lebih besar dibandingkan dengan akar gantung yang terletak jauh dari batang utama. Akar gantung yang besar dan terletak dekat batang utama menempel dan menyatu dengan batang utama sehingga batang utama pohon tampak tidak beraturan.

Buah $F$. benjamina $L$. adalah buah buni, berbentuk bulat dengan ukuran panjang kira-kira $0,5-1 \mathrm{~cm}$. warna buah saat masih muda berwarna hijau lalu berubah menjadi merah setelah tua. Bijinya berbentuk bulat, keras dan berwarna putih. (Gilman \& Watson, 2011).

Ficus sp. 1 pada penelitian ini ditemukan di habitat granit dataran rendah, habitat kerangas dan habitat batu berpasir sedangkan pada habitat rawa air tawar dan habitat dataran aluvial tidak ditemukan Ficus sp. 1. Kondisi sekeliling Ficus sp.1 ditemukan yaitu banyak tumbuhan berduri dengan kondisi tanah yang berpasir. permukaan batang kasar, memiliki cabang yang banyak dan terdapat bulu-bulu halus pada permukaan cabang. Tinggi pohon mencapai 20 meter, kulit pohon terdapat bercak-bercak putih seperti panu dan pohon tersebut apabila dilukai mengeluarkan getah berwarna putih.

Ficus sp. 2 pada Penelitian ini ditemukan di habitat granit dataran rendah, habitat batu berpasir, habitat rawa air tawar dan habitat dataran aluvial sedangkan pada habitat kerangas tidak ditemukan. Secara umum, Ficus sp. 2 ditemukan pada kondisi lingkungan sekitar yang kering maupun lingkungan berair seperti rawa.

Penelitian yang dilakukan terhadap kepadatan Ficus spp. di lima habitat yang berbeda di Stasiun Penelitian Cabang Panti Taman Nasional Gunung Palung mendapatkan hasil kepadatan tertinggi yaitu dari jenis Ficus punctata $L$. pada habitat granit dataran rendah yaitu 26 individu/ha, habitat granit dataran rendah merupakan tipe habitat dengan kondisi lingkungan berbatu yang berada pada ketinggian 200-400 m dpl. Ficus punctata $L$ memiliki nilai kepadatan tertinggi dibandingkan jenis lainnya.

Tingginya nilai kepadatan Ficus punctata $L$ yang didapatkan pada habitat granit dataran rendah menunjukkan bahwa kondisi habitat mendukung pertumbuhan jenis ini. Berdasarkan hasil pengukuran faktor lingkungan pada lokasi pengamatan didapatkan rerata $\mathrm{pH}$ tanah sebesar 6,6 , kelembaban tanah sebesar $40 \%$, suhu udara 
$27^{\circ} \mathrm{C}$ dan kelembaban udara sebesar $96 \%$. Kondisi lingkungan ini mendukung pertumbuhan $F$. punctata $L$.

Jenis Ficus yang mendominasi lokasi penelitian adalah Ficus punctata $L$. jenis ini dapat beradaptasi dengan kondisi lingkungan dan mampu bersaing dengan jenis lainnya dalam mendapatkan ruang tumbuh sehingga mempunyai kesempatan untuk memperoleh faktor-faktor lingkungan berupa cahaya, air dan unsur hara lainnya dibandingkan jenis yang lain. Hal ini sesuai dengan pendapat Sutisna (1981) yang menyatakan bahwa suatu jenis dikatakan dominan apabila jenis tersebut terdapat dalam jumlah yang besar, tersebar merata, menang bersaing, mempunyai toleransi yang tinggi terhadap kondisi lingkungan dan cocok dengan habiatnya dibandingkan spesies lain.

Ficus spp. merupakan tumbuhan yang memiliki kemampuan hidup dan beradaptasi dengan baik pada berbagai kondisi habitat baik di dataran rendah hingga di dataran tinggi. Menurut Cannon \& Leighton (2004), keanekaragaman habitat yang ada di Stasiun Penelitian Cabang Panti lokasinya saling berdampingan sehingga dapat meminimalkan adanya perbedaan curah hujan, ketinggian, musiman yang terjadi dan faktor lingkungan lainnya.

Menurut Krebs (1972) dalam Effendie (2002) kepadatan merupakan parameter populasi yang berkaitan erat dengan parameter lain yang berhubungan dengan pengelolaan lingkungan. Menurut Fachrul (2007) nilai kepadatan dapat digunakan untuk menggambarkan bahwa jenis dengan nilai kepadatan tinggi memiliki pola penyesuaian yang besar. kepadatan ditaksir dengan menghitung jumlah individu setiap jenis dalam kuadrat yang luasnya ditentukan, kemudian perhitungannya diulang di tempat yang tersebar secara acak.

Kepadatan Ficus spp. tertinggi pada habitat granit dataran rendah sedangkan kepadatan terendah pada habitat dataran alluvial. Menurut Sugyanti (2011) pertumbuhan populasi mengalami kepadatan yang bertambah dengan cepat terjadi apabila populasi ada dalam suatu lingkungan yang ideal, yaitu ketersediaan nutrisi, ruang dan kondisi lingkungan lainnya tanpa adanya persaingan. Jenis yang memiliki kepadatan yang tinggi dikarenakan mempunyai jumlah yang banyak serta penyebarannya yang luas.
Berdasarkan Tabel 3 menunjukkan bahwa hasil perhitungan Indeks Morisita pada jenis Ficus punctata $L$. di habitat granit dataran rendah bernilai 1,392 > 1 yang mengindikasikan bahwa pola penyebaran Ficus spp. pada habitat tersebut termasuk dalam kategori mengelompok sedangkan Ficus punctata L. pada habitat kerangas, batu berpasir, rawa air tawar dan dataran aluvial memiliki nilai indeks morisita $<1$ yang mengindikasikan bahwa pola penyebaran pada habitat tersebut termasuk dalam kategori seragam, sama halnya dengan jenis F.benjamina $L$, Ficus sp. 1 dan Ficus sp. 2 yang memiliki pola penyebaran seragam di semua habitat.

Hasil perhitungan indeks morisita pada penelitian ini menunjukkan bahwa hanya Ficus punctata $L$. pada habitat granit dataran rendah yang memiliki pola penyebaran secara mengelompok sedangkan yang lainnya memiliki pola penyebaran secara seragam. Hal ini sesuai dengan yang dikemukakan oleh Barbour et al. (1987) yang menyatakan bahwa pola distribusi spesies tumbuhan cenderung mengelompok, sebab tumbuhan bereproduksi dengan menghasilkan biji yang jatuh dekat induknya atau dengan rimpang yang menghasikan anakan vegetatif masih dekat dengan induknya. Hasil pada penelitian ini didapatakan bahwa jenis Ficus lebih cenderung pada pola penyebaran seragam. Hal ini disebabkan tingginya persaingan sehingga timbul kompetisi yang mendorong pembagian ruang hidup yang sama. Menurut Crawley (1986) pola sebaran seragam artinya jarak antara individu dengan individu lain pada jenis yang sama dalam satu wilayah adalah sama atau hampir sama.

Pola penyebaran mengelompok dipengaruhi oleh faktor internal dan eksternal dari tumbuhan Ficus seperti pola reproduksi baik secara vegetatif maupun generatif dan kondisi habitat tempat tumbuhnya. Penyebaran biji dapat terjadi dekat tumbuhan induk karena hewan-hewan yang memakan buah Ficus dan menjatuhkan bijinya dibawah pohon Ficus atau terjadi secara alami dengan bantuan angin sehingga penyebaran biji tersebar mengelompok.

Hasil perhitungan indeks morisita pada penelitian ini tidak menunjukkan adanya pola penyebaran Ficus spp. secara acak. Penyebaran secara acak relatif jarang di alam, hanya terjadi apabila adanya persaingan yang kuat diantara individu-individu Ficus spp. dalam memperoleh nutrisi dan ruang sehingga mendorong pembagian ruang hidup yang sama antarindividu. Hal ini sesuai dengan 
pendapat Odum (1993) dalam Indriyanto (2006) bahwa kompetisi yang kuat antarindividu dalam suatu populasi akan mendorong terjadinya pembagian ruang yang sama.

\section{UCAPAN TERIMA KASIH}

Penulis mengucapkan terimakasih kepada Dr. Rafdinal S. Si., M. Si dan Riza Linda S. Si., M. Si sebagai dosen pembimbing pertama dan kedua. Pihak pemberi Beasiswa Peduli Orangutan Kalimantan, Yayasan Palung, Balai Taman Nasional Gunung Palung, Orangutan Republic Foundation, dan Kepala SPCP beserta staff dan asisten lapangan yang telah membantu pelaksanaan penelitian.

\section{DAFTAR PUSTAKA}

Barbour, G, M, Busk, J, K \& Pitts, W, D, 1987, Terrestrial Plant Ecology, Cummings Publishing Company Inc. New York

Berg, C, C \& E, J, H, Corner, 2010, Moraceae, Flora malesiana, 17(2): 1-730 Boer, E \& M, S, M, Sosef, 1998, General Part of Ficus, Plant Resources of South EastAsia, Timber Trees, Backhuys Publisher, Leiden, p, 233-238

Brower, J \& Zar J, H, 1977, Field and Laboratory Methods for General Ecology, W, C, Brown Company Publishers, Dubuque, Iowa

Boer, E \& M, S, M, Sosef, 1998, General Part of Ficus, Plant Resources of South East Asia, Timber Trees, Backhuys Publisher, Leiden, p, 233-238

Cannon, C, H \& M, Leighton, 2004, Tree species distributions across five habitats in a Bornean rain forest, Journal of Vegetation Science 15:257-266

Crawley, M, J, 1986, Plant Ecology, Cambridge Center, MA: Blackwell Scientific Publications

Effendi, M, I, 2002, Biologi Perikanan, Yayasan Pustaka Nusatama, Yogyakarta

Fachrul, M, F, 2007, Metode Sampling Bioteknologi, Bumi Aksara, Jakarta

Gilman, E, F \& Watson, D, G, 2011, Syzygium oleana, Forest Service Departement of Agriculture, United States

Hao, G, Y, Cao, K, F \& Goldtein G, 2016, Hemiepiphytic trees: Ficus as a modelsystem for understanding hemiepiphytes, Topical Tree Physiol 6, DOI: 10.1007/978-3-319-27422-5_1
Hemmer, W, Focke, M, Gotz, M, Jarisch, R, 2004, Sensitization to Ficus benjamina, Relationship to Natural Rubber Latex allergy and Identification of Foods Implicated in the Ficus Fruit Syndrome, Clinical and Experimental Allergy, 34(8),1251- 1258,http://doi.org/cfp633

Indriyanto, 2006, Ekologi Hutan, Bumi Aksara, Jakarta

Krebs, C, J, 1972, Ecology The Experimental Analysis of Distribution and Abundance, Third Edition, Harper and Rowl Publ, New York

Krebs, C, J, 1989, Ecological Methodology, Harper Collins Publishers, University of British Columbia, Columbia

Muhlis, M, S, 2017, Preferensi Pakan Orangutan (Pongo pygmeus wurmbii) di Stasiun Penelitian Cabang Panti, Taman Nasional Gunung Palung, Kalimantan Barat, Skripsi, Universitas Tanjungpura, Pontianak

Odum, E, 1993, Dasar-Dasar Ekologi, Universitas Gadjah Mada Press, Yogyakarta

Rusda, M, Y, 2013, Perilaku Bersarang Orangutan Kalimantan (Pongo pygmaeus wurmbii, Tiedman 1808) di Tipe Habitat yang Berbeda di Stasiun Penelitian Cabang Panti Taman Nasional Gunung Palung Kalimantan Barat, Skripsi, Universitas Islam Negeri Syarif Hidayatullah, Jakarta

Sidiq, M, Nurdjali, B, \& Idham, M, 2015, Karakteristik dan Kerapatan Sarang Orangutan (Pongo Pygmaeus Wurmbii) di Hutan Desa Blok Pematang Gadung Kabupaten Ketapang Propinsi Kalimantan Barat, Fakultas Kehutanan Universitas Tanjungpura Pontianak, Jalan Imam Bonjol Pontianak, Jurnal Hutan Lestari, Vol. 3, no. 2 , hal. $32-33$

Sugiyanti, Hardianyah, Amintarti, S, 2011, Jenis dan Kerapatan Tumbuhan Meranti Penghasil Damar yang Terdapat di Hutan Hamurau Dusun Puli'in Desa Artain Kecamatan Aranio Kabupaten Banjar, Jurnal Wahana Bio, VI :60-81

Sutisna, 1981, Komposisi Hutan Bekas Tebangan di Batulicin Kalimantan Selatan, Deskripsi dan Analisis Laporan No 328, Balai Penelitian Hutan, Bogor

Ulum, S, 2009, Manfaat Beringin Putih Dalam Pembangunan Kawasan Hutan,Kabar Indonesia, Jakarta 